\title{
Türkiye Ekonomisinde Politik İstikrarsızlık-Makro Ekonomik Performans İlişsisi
}

\section{Selim SANLISOY ${ }^{1}$}

\author{
Mehmet ÇETIN²
}

\begin{abstract}
$\ddot{O} z$
Ekonomik kaynakların belirlenmiş makro ekonomik hedeflere ulaşılması amacıyla optimal oranlarda bir araya getirilerek kullanılması sonucunda elde edilen başarı, makro ekonomik performans olarak tanımlanabilir. 1990'll ylllardan itibaren ülkelerin ekonomik performanslarının analizinde politik istikrarsızlık kendisine daha fazla yer bulmuştur. Politik istikrarsızlık, beklentiler üzerinden ilgili birimlerin makro ekonomik performansların etkileyebilmektedir. Ancak makro ekonomik alanda yaşanan sorunlar da ülkelerde politik istikrarsızlık yaratabilmektedir. Sonuç olarak değişkenler arasında her iki yönde nedensellik ilişkisinin ortaya çıkması olasıdır. Bu çalışmada politik istikrarsızlık ile makro ekonomik performans değişkeni arasındaki nedensellik ilişkisinin yönü geliștirilen makro ekonomik performans endeksi ve ekonometrik yöntemlerle belirlenecektir.
\end{abstract}

Anahtar Kelimeler: Makro Ekonomik Performans, Politik Istikrarsızlık, Türkiye Ekonomisi.

JEL Sinıflandırma Kodları: O11, E02, E6, P47.

\section{The Relationship Between Political Instability and Macro Economic Performance in the Turkish Economy}

\begin{abstract}
The success achieved by the combination of economic sources in optimal rates in order to reach the specified targets can be defined as economic performance. Following the nineties political instability took place more in the analysis of the macro economic performances of the states. The political instability can affect the macro economic performance through the expectations. However the problems experienced in the economic field can also create political instability. As a result, it is possible for a two-way causality to occur between these variables. In this study the direction of the causality between the political instability and macro economic performance will be determined by a macroeconomic performance index developed and by using econometric methods.
\end{abstract}

Keywords: Macro Economic Performance, Political Instability, Turkish Economy.

Jel Classification Codes: O11, E02, E6, P47.

${ }^{1}$ Doç. Dr., Dokuz Eylül Üniversitesi, İktisadi ve İdari Bilimler Fakültesi, İktisat Bölümü, selim.sanlisoy@deu.edu.tr

${ }^{2}$ Yrd. Doç. Dr., Dokuz Eylül Üniversitesi, İktisadi ve İdari Bilimler Fakültesi, İktisat Bölümü, mehmet.cetin@deu.edu.tr 


\section{GíRIŞ}

\section{S.ŞANLISOY -M.ÇETINN}

Bir ekonomide ekonomi politikasının amac1, ekonomik birimlerin davranışlarının ve kararlarının etkilenmesiyle ekonomik alandaki hedeflerin gerçekleştirilmesidir. Makro-ekonomik süreç içerisinde ortaya çıkan ekonomik büyüme, istihdam, fiyatlar genel düzeyi, faiz oranı, kamu kesiminin borcu, cari işlemler dengesi açığı ve bütçe açığına ilişkin alt amaçlar bir bütünlük içerisinde refah ve sosyal hasılanın maksimizasyonu amacını meydana getirmektedir. Söz konusu amaca ulaşma derecesi de makro ekonomik performans düzeyini göstermektedir. Makro ekonomik performans olarak ifade edilen başarı göstergesinin tek bir amaçtan meydana gelmediği dikkat edilmesi gereken bir durumdur. Öte yandan alt amaçların öncelik sıralaması ise toplumun değer yargıları, iktidarın sahip ideolojiler, farklı baskı ve çıkar gruplarının hedefleri ile ülke ekonomisinin mevcut durumunun belirlenmiş olan amaçlardan sapma derecesine bağlı olarak ortaya çıkmaktadır (Erkan, 2000: 20, 156).

Ülkelerin ekonomi politikası yönetiminin başarısını gösterecek olan makro ekonomik performansın ölçümü bir takım güçlükler içermektedir. Bu güçlüklerden ilki belirlenen amaç değişkenlerinin bir arada değerlendirilmesine karşın, bu değişkenlerin ortak bir birimle ifade edilememesi ve her bir değişkende ortaya çıkan değişimin önem derecesinin farklı olmasıdır. Belirlenen amaçlar arasındaki ilişkiler ise ikinci güçlüğü oluşturmaktadır. Bu, makro ekonomik amaçlar arasında bir çatışmanın olabileceği anlamına gelmektedir (Güran ve Tosun, 2005: 89-115; Breuss, Luptacik ve Mahlberg, 2000: 3-4). Yüksek bir büyüme oranı ile birlikte düşük bir enflasyon oranı, düşük işsizlik oranı ve pozitif dış ticaret dengesi ekonomi politikasına yön veren karar birimlerinin dört temel hedefini meydana getirmektedir (Mohamad, 2007: 29-40). Söz konusu değişkenlerdeki başarı performansı, OECD tarafindan "sihirli elmas" (magic diamond) olarak adlandırılmaktadır. Dolayısıyla OECD (1987)'ye göre makro ekonomik performansı teşkil eden dört bileşen bulunmaktadır.

Ekonomik performansı etkileyen çok sayıda politik ve ekonomik etken bulunmaktadır. Bunlardan biri de politik istikrarsılıktır. Şanlısoy (2010)'da ortaya 
konulduğu üzere politik istikrarsızlık, ekonomik süreç politikası amaçlarının tümü üzerinde etkileme gücüne sahiptir. Bu durumda da ekonomik performans üzerinde belirleyici hale gelmektedir.

Politik istikrarsızlık politik alanda ortaya çıkan kararsızlık ya da değişen yapısal koşullar olarak düşünülebilir. Dolayısıyla politik istikrarsızlık otokratik rejimlerden demokratik rejimlere kadar farklı rejim tiplerinde ortaya çıabilmektedir. Literatürde politik rejim tiplerinin ekonomi üzerindeki etkilerinin net bir şekilde ortaya konulamamış olması politik istikrarsızlığın modellere dahil edilmesi sonucunu beraberinde getirmiştir.

Politik rejim tipleri ve bu rejimlere ilişkin uygulama süreçlerindeki farklılıklara bağlı olarak politik istikrarsızlık konusunda gerek bir kavram birliğinin oluşturulması noktasında gerekse istikrarsızlığın kaynakları noktasında bir uzlaşmaya varılamamıştır. Bununla birlikte politik istikrarsızlık kavramında ilk olarak zorla anayasal sistemi değiştirme çabasına girme; ikinci olarak anayasal düzen içerisinde politik süreçte meydana gelen bazı olgular olmak üzere iki temel durum ön plana çıkmaktadır. Bunlar; seçmenlerin kutuplaşması, politik parçalanma, koalisyon ya da azınlık hükümetleri, hükümetlerin değişim sıklığ 1 vb.dir. Bu konu ile ilgili literatürde önemli bir yer tutan Alesina ve Perotti (1993)'e göre politik istikrarsızlık;

- Anayasal olan veya olmayan hükümet değişiklikleri,

- Sosyal huzursuzluk ve politik şiddet

başlıkları altında toplanmaktadır. Söz konusu başlıklar dikkate alındığında politik istikrarsızlığın demokratik olarak tanımlanan sistemlerde ortaya çıkması muhtemel olduğu gibi otokratik yönetim biçimlerinde de ortaya çıkabileceği daha iyi anlaşılmaktadır. Otokratik yönetim biçimlerinde istikrar, egemenlik gücünü elinde tutan kişiye bağlıdır. Söz konusu kişinin devrilmesi, iktidardan uzaklaştırılması, ölmesi vb. istikrarsızlığı meydana getirir (Yayla, www.liberal-dt.org.tr/yayla/ayistikrarsõzlõk.htm). Yayla'ya göre politik istikrarsılık egemen kişi kaynaklı gelişmelerden meydana geliyor olsa da demokratik sistemlerdeki olası savaş ya da 


\section{S.ŞANLISOY -M.ÇETIN}

sınır çatışmaları gibi bazı politik istikrarsızlık kaynaklarının otokratik sistemlerde de görülme ihtimali bulunmaktadır. Demokratik sistemlerde ise politik istikrarsızlığın kaynakları (Eren ve Bildirici, 2001: 31):

- Parlamento içerisindeki kutuplaşmalar,

- Koalisyon hükümetleri,

- Seçmenlerin kararsız tutumları,

- Seçimlerin zamanlaması ve seçim sürecinin yönetimi,

- Hükümet değişikliklerinin sıklığı.

$\mathrm{Bu}$ çalışmada ele alınan dönem dikkate alındığında Türkiye'de politik istikrasızlığın sıklıkla ortaya çıktı̆̆ söylenebilir. Söz konusu dönemde Türkiye’de politik istikrasızlığın kaynakları (Şanlısoy ve Kök, 2010b:103, Yalçınkaya vd., 2016:164-165):

- Askeri müdahaleler,

- Uygulanan ekonomi politikalarına bağlı olarak ortaya çıkan olumsuzluklarla beraberinde yaşanan ekonomik krizler, yolsuzluklar ve politik alanla politikacılara duyulan güvensizlik, seçmenleri sürekli olarak yeni arayışların içine sokmuştur. $\mathrm{Bu}$ durum politik bir parçalanmışlı̆̆ın ortaya çıkmasına neden olmuştur. Politik parçalanmaya bağlı olarak 1991-2002 döneminde bir taraftan zayıf ve uyumsuz koalisyon hükümetleri öte taraftan marjinal partiler iktidara gelmişlerdir. 1980 yılından önce toplumda sağ - sol ayrımına bağlı olarak görülen kutuplaşma, 1980 sonrasında laik - antilaik şeklide dönüşmüştür. Söz konusu kutuplaşma askeri müdahalelerin temel nedeni olmuştur.

- Kurulan hükümetlerden hemen hiçbirisi yasal süresini tam olarak dolduramamış, dönem içerisindeki 2011 ve 2015 Haziran seçimleri istisna olmak üzere tüm seçimler erken seçim olmuştur. Haziran 2015 seçimlerinin sonuçları doğrultusunda hükümet kurma çabalarının bir sonuç vermemesi üzerine Kasım 2015 'te erken seçim yapılmasına karar verilmiştir. Ayrıca incelenen dönemde hükümetlerin yaşam sürelerinin kısa olduğu bir başka ifadeyle hükümetlerin 
değişim sıklığının yüksek olduğu söylenebilir. 1983-2007 döneminde, 18 hükümetin (45. ve 62. Hükümetler dahil) kurulduğu ve hükümetlerin ortalama ömrünün iki yıldan kısa olduğu bilinmektedir. Dolayısıyla bir yandan sıklıkla yaşanan hükümet değişimleri diğer yandan genel ve yerel seçimlerin sıklı̆̆ hem ekonominin politik manipülasyonuna hem de politik istikrarsızlığa zemin hazırlamıştır. $\mathrm{Bu}$ durum ekonomide yaşanan ekonomik sorunların ortadan kaldırılmasına yönelik gerçekçi ekonomi politikalarının yürürlüğe konmasına da mani olmuş ve ekonomik sorunlar derinleşmiştir. Gerek bu durum gerekse yapılan seçimlerin (milletvekilliği genel seçimleri ve yerel seçimler) sıklığı, bir yandan ekonominin politik manipülasyonuna ve politik istikrarsızlığa neden olurken diğer yandan yaşanan ekonomik sorunlara kalıcı çözümler getirilmesini engellemiştir.

- Başta PKK terör örgütünün eylemleri ile dönem içinde yaşanan terör faaliyetleri,

- Gezi Parkı olayları,

- Paralel devlet yapılanmasına ilişkin soruşturmalar,

- Politik istikrarsızlı aslında sadece yurtiçi gelişmelerden kaynaklanmamaktadır. Özellikle komşu ülkelerle olmak üzere dış dünya ile bağlantılı olarak da yaşanabilmektedir. $\mathrm{Bu}$ bağlamda Türkiye'nin sınır komşularıyla yaşadığı problemlerle içerisinde bulunduğu coğrafyanın devamlı olarak yeni problemler orta çıkarması da politik istikrarsızlığın önemli bir kaynağıdır. Örneğin Irak ve Suriye'deki karışıklıklar, Rusya ile yaşanan problemler ve DAEŞ terörü yakın dönemdeki dış kaynaklı politik istikrarsızlık kaynaklarının en önemlileridir.

Tüm bu olaylar ve süreçler dikkate alındığında ele alınan dönem açısından Türkiye'nin oldukça farklı kaynaklardan beslenen bir politik istikrarsızlık sorununun mevcut olduğu söylenebilir. Bu durum, Türkiye'nin her anlamda gelişme göstermesinin ve ülkedeki refah artışının önündeki en önemli engellerden biridir.

Politik istikrarsızlık, yarattığı politik belirsizlik ve risk ile iktisadi karar birimlerin öngörü yetisini sinırlamakta ve beklentilerine yön vererek ülke 


\section{S.ŞANLISOY -M.ÇETIN}

ekonomilerini etkilemektedir. Buna bağlı olarak da politik istikrar veya istikrarsızlıkla ekonomik değişkenler arasındaki etkileşim hem makro hem de mikro ekonomik düzeyde ortaya çıkmaktadır. Bu bağlamda çalışmada öncelikle literatürden hareketle politik istikrarsızlığın makro ekonomik performans üzerindeki etkileri ve bu etkilerin hangi mekanizmalarla meydana geldiği ortaya konulmaya çalışılacaktır. Daha sonra Türkiye ekonomisine ilişkin bir makro ekonomik performans göstergesi oluşturulacaktır. Ardından oluşturulan değişken ile politik istikrarsızlık arasındaki nedensellik ilişkisi ekonometrik analizler yardımıyla incelenecektir. Çalışma sonuç ve politika önerileri ile son bulacaktır.

2. MAKRO EKONOMIK PERFORMANS -POLITIK İSTIKKRARSIZLIK ILIŞKIISI: LITERATÜR TARAMASI

Politik ve kurumsal faktörlerin ekonomik performans üzerindeki etkisi Adam Smith’ten beri gözlenen bir durumdur. İktisat literatüründe politik istikrarsılılı ve ekonomik performansa ilişkin çalışmalar, her iki gösterge için de seçilen değişkenlerin farklılığı ve değişkenler arasındaki nedensellik ilişkilerinin yönüne ilişkin beklentilere bağlı olarak farklılaşmaktadır. Ekonomik büyüme ve ekonomik kalkınmaya ilişkin değişkenler birçok çalışmada ekonomik performansı temsilen analizlere dahil edilmiştir. Bazı çalışmalarda da oluşturulan ekonomik performans endeksi, ekonomik performans değişkeninin yerine kullanılabilmektedir. Benzer şekilde politik istikrarsızlık da seçimler, faiz yahut döviz kuru gibi ekonomik değişkenler, askerî müdahale ihtimali, politik risk endeksi ve terör faaliyetlerine ilişkin veriler tarafından temsil edilebilmektedir.

Esas itibariyle ekonomik değişkenlerle politik değişkenlerin birbirlerini etkileme olasılıkları hemen her zaman bulunmaktadır. Politik istikrarsızlığın ekonomik performans üzerindeki etkisi iki farklı kanal üzerinden gerçekleşmektedir (Şanlısoy, 2010: 198-200) . Birinci kanal politik istikrarsızlığın ekonomik değişkenleri doğrudan etkilemesine dayanmaktadır. Örneğin, politik istikrarsızlık durumunda gerek doğrudan yabancı sermaye yatırımları gerek finansal sermaye yatırımları ve gerekse beşeri sermaye ülkeyi terk edebilmektedir. $\mathrm{Bu}$ durum özellikle tasarruf açığı bulunan gelişmekte olan ülkeler dikkate 
alındığında ekonomik büyümeyi olumsuz yönde etkileyebilmektedir. Öte yandan ekonomide yatırımların azalması istihdamı azaltarak işsizlik oranının artmasını da beraberinde getirmektedir. İkinci kanal olan dolaylı kanal ise politik istikrarsızlığın geleceğe ilişkin bir belirsizlik ortamı yaratmasına bağlı olarak ortaya çıkmaktadır. $\mathrm{Bu}$ durumda politik istikrarsızlığın makro ekonomik performans üzerindeki etkisi, özellikle geleceğe ilişkin belirsizliği arttırmasından kaynaklanmaktadır. Söz konusu belirsizlik gerek ekonomik gerekse politik karar birimlerinin davranışları üzerinde etkili olmaktadır. Böylece makro ekonomik performansı etkilemektedir. Örneğin; bir ekonomide politik istikrarın bulunması girişimcilerin geleceği daha iyi bir şekilde tahmin edebilmelerini sağlayarak daha uzun vadeli ve kalıcı yatırımlara yönelmelerini beraberinde getirmektedir. $\mathrm{Bu}$ durum büyüme ve istihdam üzerinde olumlu etki yaratmakta ve makro ekonomik performansın artmasını beraberinde getirmektedir. Bir diğer örnek politik karar birimleri dikkate alınarak verilebilir. Tekrar seçilip seçilemeyeceği belirsiz olan politik iktidarlar rant kollama faaliyetleri içerisine girerek bir yandan ekonomik kaynakların etkinsiz dağılımına neden olarak diğer yandan gelir dağılımını kendi seçmenleri lehine değiştirme yoluyla gelir dağılımını bozarak makro ekonomik performansın olumsuz yönde etkilenmesine neden olabilir.

Politik istikrarsızlığın ifade edilen kanal ve mekanizmalarla makro ekonomik performans üzerinde olumsuz etkiler ortaya çıkarması ile beraber söz konusu ilişkinin ters yönlü olarak meydana gelmesi de olasıdır. Diğer bir deyişle, makro ekonomik performansın düşük kalması ya da halkın refah seviyesinde düşüş, politik istikrarsızlığı ortaya çıkarabilir. Söz konusu etkileşimi ortaya çıkarabilecek ilk kanal, düşük performansın hükümetlerin değişme olasılıklarını arttırmasına bağlı olarak oluşmaktadır. Bu süreç, politik konjonktür teorilerinde ortaya konulan demokratik sistemlerde hükümetlerin tekrar seçilebilme olasılıklarının seçimlerin hemen öncesindeki ekonomik performanslarına bağlı olmasıyla açıklanmaktadır. Ekonomik büyüme performansının yetersiz olması hükümetlerin değişim sıklığını ve erken seçim olasılıklarını arttırmaktadır. Otokratik yönetimlerdeyse yetersiz büyüme halkın hoşnutsuzluğunu artırarak iktidar karşıtı faaliyetlere girişme 


\section{S.ŞANLISOY -M.ÇETIN}

eğilimlerini artırmakta ve dolayısıyla darbe veya devrimlere uygun bir ortam meydana getirmektedir (Telatar, 2003: 76-77). İkinci olarak, ekonomik büyüme; farklı çıkar grupları arasında güç dengesinin tekrardan düzenlenmesini beraberinde getirerek koalisyon hükümetlerinin bozulmasına böylece politik istikrarsızlığa neden olabilir. Bir başka ifade ile MÖ 4. yüzyılda Platon'un ifade ettiği gibi gelir ve servet eşitsizlikleri politik istikrarsızlığı ortaya çıkarabilmektedir.

Değişkenler arasındaki nedenselliğin yönü politik istikrarsızlık ve ekonomik performans arasındaki ilişkiyi analiz eden çalışmalarda merkezi bir rol oynamaktadır. Bu bağlamda ampirik çalışmalar üç düşünce akımı çevresinde gelişmiştir. Bunlardan birincisi politik istikrarsızlığın daha düşük bir ekonomik büyümeye yol açtığını, ikincisi ekonomik performansın politik istikrarı tetiklediğini ve üçüncüsü ise nedenselliğin çift yönlü olduğunu ileri sürmektedir.

Olson (1991), demokratik liderlerin yeniden seçilebilmek umuduyla istikrarlı bir ekonomi yaratma çabaları üzerinden politik istikrarsızlığın daha düşük bir ekonomik büyümeye neden olacağı fakat nedensellik anlamında tersinin geçerli olmadığı sonucuna ulaşmıştır.

Bienen vd. (1993), büyümenin yönetim değişikliği üzerindeki etkisini araştırmışlar; mevcut ve geçmiş döneme ilişkin büyüme oranlarının yüksek olmasının iktidar değişikliği olasılığını düşürdüğünü belirtmişlerdir. Dolayısıyla çalışmada ekonomik büyümeden politik istikrara doğru bir nedensellik ilişkisinin varlığı bir başka ifadeyle refah artışının politik istikrarın gerçekleştirilmesinde önemli bir etkisinin olduğu ifade edilmektedir.

Ekonomik performansın politik istikrar üzerinde etkili olduğu düşüncesinden hareket eden Zablotsky (1996), çalışmasının odak noktasına askeri darbeleri oturtmaktadır. Çalışmada esas belirleyici unsur, askerî sınıf mensuplarının darbeye katılma kararlarında belirleyici olan kamu mallarına yönelik özel çıkar motivasyonlarıdır. Dolayısıyla çalışmada nedenselliğin yönü, ekonomik unsurlardan politik unsurlara doğrudur. 
Politik istikrarsızlığın daha düşük büyümeye yol açacağını ileri süren çalışmalardan Alesina vd. (1996), politik istikrarsızlıkla ekonomik büyüme arasında karşılıklı bir ilişkinin bulunduğunu ortaya koymuşlardır. Buna göre, politik istikrarsızlık yatırımların hacmini ve etkinliğini düşürerek ekonomik büyümeyi olumsuz yönde etkilemektedir. Ayrıca büyüme ve gelir üzerinde meydana gelecek negatif bir şokun politik istikrarsızlığın artmasını beraberinde getirdiği çalışmada ortaya konulmuştur.

Asteriou ve Price (2001), 1961-1997 döneminde İngiltere ekonomisinde politik istikrarsızlığın büyüme üzerine etkilerini araştırmışlar ve politik istikrarsızlıktan büyümeye doğru tek yönlü bir nedenselliğin bulunduğu bulgusuna ulaşmışlardır. Ayrıca politik istikrarsızlık büyümeyi olumsuz yönde etkilemektedir.

Campos ve Nugent (2002), 98 gelişmekte olan ülke için 1960 - 95 döneminde politik istikrarsızlık ve ekonomik büyüme arasındaki ilişkiyi dengesiz panel yöntemi ile ampirik olarak test etmiş fakat uzun vadeli negatif bir nedensellik ilişkisinin varlığını ortaya koyamamıştır. Yapılan duyarlılık analizinin neticesinde söz konusu ilişkinin kısa vadede gerçekleştiği sonucu elde edilmiştir.

Berthelemy, Kauffmann, Renard ve Wegner (2002), seçilmiş Afrika ülkeleri için politik istikrarsızlık, politik rejimler ve ekonomik performans arasındaki ilişkiyi 1996-2001 dönemi çeyrek dönem verileriyle Granger nedensellik testiyle araştırmışlardır. Sonuçlar, politik gelişmelerin sadece politik olaylarla değil aynı zamanda ekonomik faktörlerle de yakın ilişki içerisinde olduğunu göstermektedir. Elde edilen bir diğer önemli bulgu da nedenselliğin ekonomik büyümeden politik istikrarsızlığa doğru olduğu ve yaşanan ekonomik büyümenin politik istikrarsızlığı yumuşattığ1 yönündedir.

Politik istikrarsızlık ve ekonomik performans arasındaki nedensellik ilişkisinin çift yönlü olduğunu öne süren çalışmalardan Kirmanoğlu (2003), ekonomik refah ile politik özgürlük arasındaki ilişkiyi Granger nedensellik analizi ile 1972 - 2001 dönemi için 19 az gelişmiş ülke bağlamında ele almaktadır. Çalışmada ekonomik refah göstergesi olarak kişi başına reel gayri safi yurt içi hasıla değişkeni 


\section{S.ŞANLISOY -M.ÇETIN}

kullanılmıştır. Çalışmanın bulguları farklı ülkeler için farklı sonuçlar ortaya koymaktadır. Bolivya ve Malezya için politik özgürlüklerdeki artış daha yüksek bir ekonomik büyüme yaratırken; Kore, Panama ve Türkiye için daha yüksek ekonomik büyüme politik özgürlüğü arttırmaktadır.

Sakamato (2005), 17 OECD ülkesini ele aldığ çalışmasında 1961-1998 döneminde zayıf hükümetlerin merkez bankasının bağımsız olması koşulu altında büyüme performansını artırdığı sonucuna ulaşmıştır.

Butkiewicz ve Yanıkkaya (2005), sosyo-politik istikrarsızlığın uzun dönem büyüme üzerindeki etkisini inceledikleri çalışmalarında, sosyo-politik istikrarsızlıkla büyüme arasında basit ve doğrusal bir ilişkinin kurulamayacağına ilişkin bir sonuca varmışlardır. Özellikle hükümet istikrarsızlığının ve sosyal istikrarsızlı̆̆ın büyüme üzerine etkisinin önemsiz; politik şiddet göstergelerininse önemli ve negatif bir etkisinin olduğunu belirlemişlerdir. Ayrıca sosyo-politik istikrarsızlığın büyüme üzerine olan olumsuz etkilerinin, düşük gelirli ve zayıf bir demokratik yapıya sahip ülkelerde orta ve yüksek gelirli, aynı zamanda demokrasi düzeyinin gelişmiş olduğu ülkelerden, daha küçük olduğu sonucuna ulaşmışlardır.

Nedenselliğin yönünden ayrı olarak analizlerin sonucunu etkileyen önemli bir husus; analizlerde kullanılan temsili değişkenlerdir. Birçok çalışmada ekonomik performans göstergesi olarak ekonomik büyüme, refah yahut kalkınma değişkenleri tercih edilmektedir. Türkiye'yi analize dahil eden çalışmalarda pek kullanılmamakla birlikte tercih edilen bir diğer gösterge seçimi ise oluşturulan endekslerden yana olmaktadır. Büyümenin makro ekonomik performans göstergesi olarak ele alındığı çalışmalardan Londregan ve Poole (1990)'un 1950 - 1982 dönemi için 121 ülkeyi kapsayan analizleri neticesinde artan politik istikrarsızlı̆̆ın daha düşük bir büyümeye neden olacağına dair bir bulgu elde edilmemekle birlikte tam tersine düşük büyüme oranlarının politik istikrarsızlığı arttıracağ 1 sonucuna ulaşmıştır.

De Haan ve Siermann (1996), 97 ülke için 1963-88 dönemini kapsayan analizlerinde politik istikrarsızlık verisi olarak hükümet değişimleri ve ekonomik 
performans değişkeni olarak da reel milli gelirdeki artışı kullanmıştır. Çalışmada elde edilen bulgular, politik istikrarsızlı̆̆ın sermaye ve işgücü arzını azaltarak; artan risk ile birlikte yatırımları caydıracağını ve politik kargaşanın beyin göçüne ve sermayenin kaçışına neden olacağını ileri sürmektedir. Bu çalışmada da nedenselliğin yönü politik istikrarsızlıktan ekonomik performansa doğrudur.

Tekil çalışmalardan Haber ve Razo (1998), Meksika örneğinde politik istikrarsızlık ve ekonomik performans arasındaki ilişkiyi mülkiyet hakları bağlamında incelemektedir. Barro (1990)'nın bulguları çerçevesinde mülkiyet haklarını sınırlayan politik istikrarsızlık ve kurumsal değişikliklerin ekonomik performans üzerinde olumsuz bir etkiye sahip olması beklenen bir durum iken Haber ve Razo'nun çalışmasında politik istikrarsızlık ile mülkiyet haklarının güvenliği arasında herhangi bir bağlantı olmasının zorunlu olmadığı dolayısıyla mülkiyet hakları korunan yatırımcıların yatırımlarını yapmaya devam edecekleri ileri sürülmektedir.

Fielding (2001), çalışmasında intifada dönemi için İsrail ekonomisinde politik istikrarsızlık ve ekonomik performans ilişkisini ele almıştır. Çalışmada makro ekonomik performans göstergesi olarak yatırım performansı seçilmiş ve 1987-98 dönemi çeyrek dönemlik veriler kullanılarak analiz edilmiştir. İntifada sürecinde öldürülen İsraillilerin sayısı ve Batı Şeria ve Gazze'deki Yahudi yerleşimlerinde görülen artış yatırımların politik belirleyicileri olarak belirlenmiştir. İsrail'de yaşanan politik istikrarsızlık, temel ekonomik ilişkileri etkilememekle birlikte karş111klı ölüm olayları toplam yatırımlar üzerinde belirleyici olmaktadır. Buna göre her türlü şiddet unsuru yatırım talebini baskılamaktadır.

Ahmed ve Pulok (2013), 1894 - 2009 dönemi için Bangladeş örneğinde eşbütünleşme ve sınır testi aracılığıyla politik istikrar ve ekonomik performans arasındaki ilişkiyi analiz etmiş ve kısa vadede değişkenler arasında pozitif bir ilişki elde ederken uzun vadede politik istikrarsızlıkla ekonomik büyüme arasında ters yönlü bir ilişki bulunduğu sonucuna ulaşmışlardır. Elde edilen bulgular, politik istikrarın uzun vadede işlevsiz olduğunu ve ekonomik büyümenin yavaşlamasına neden olacağını ileri süren Olson (1982) ile tutarlılık göstermektedir. Olson 


\section{S.ŞANLISOY -M.ÇETIN}

(1982)'ye göre uzun vadede toplumların yeni teknolojilere uyum sağlama ve kaynakları değişen ekonomik koşullara göre yeniden tahsis etme yeteneği sekteye uğrayacaktır.

Karahan ve Karagöl (2014), hükümet istikrarını politik istikrar göstergesi olarak aldıkları çalışmalarında politik istikrarsızlığın makro ekonomik performansı olumsuz yönde etkilediğini vurgulamışlardır. Çalışmada makro ekonomik performans göstergesi olarak ekonomik büyüme, kamu maliyesi, enflasyon değişkenleri ayrı ayrı ele alınmıştır.

Parlakyıldız (2015), Latin Amerika ülkeleri için 1999-2013 dönemini incelediği çalışmasında da enflasyon oranı, işsizlik oranı ve politik istikrarsızlık seviyesinin ekonomik performans üzerindeki etkisini analiz etmiştir. Makro ekonomik performans göstergesi olarak ekonomik büyümenin alındığı çalışmada işsizlik oranıyla politik istikrarsızlık seviyesinin ekonomik performansı olumsuz etkilediği ancak enflasyon oranının ekonomik performans üzerinde hiçbir etkisi olmadığ sonucuna ulaşılmıştır.

Analizlerine Türkiye'yi de dahil eden çalışmaları değişkenler arası nedensellik ilişkisinin yönü ve ekonomik performans göstergesi olarak kullanılan değişkenlerin tasnifi üzerinden ayrıca ele alırsak; bu çalışmalardan İsmihan, Kıvılcım ve Tansel (2002), Fisher (1993)'ü takip ederek enflasyon oran1, kamu borcunun GSMH'ye oranı ve dış borcun GSMH'ye oranı verilerinin kullanılmasıyla oluşturdukları makro ekonomik istikrarsızlık endeksi, özel ve kamu sektörü yatırımları ve gayri safi milli hasıla arasındaki ilişkiyi Johansen koentegrasyon analiziyle ele almışlardır. Elde edilen bulgular; makro ekonomik istikrarsızlığın sermaye oluşumu ve ekonomik büyüme üzerinde olumsuz bir etkiye sahip olduğunu ortaya koymaktadır. Elde edilen bir diğer bulgu da kısa ve orta vadede kamu ve özel sektör yatırımlarının birbirini tamamlayıcı olduğudur. Makro ekonomik istikrarsızlık söz konusu tamamlayıcılık özelliğini de ortadan kaldırmaktadır.

Tosun, Güran ve Ulucan (2008), çalışmalarında Türkiye'nin de aralarında bulunduğu Orta Doğu ve Kuzey Afrika (MENA) ülkeleri için 1987 - 2003 
dönemini ele almışlardır. Çalışmada politik istikrarsızlık, yatırım profili ve enflasyon, cari işlemler dengesi fazlası/açığı ve ekonomik büyüme oranları tek bir ölçüte dönüştürülerek elde edilen makro ekonomik performans verisi arasındaki ilişki, türetilen Malmquist Verimlilik Endeksi yardımıyla analiz edilmiştir. Bulgulara göre Körfez Savaşı'nı takip eden dönemde MENA bölgesi ülkelerinde makro ekonomik performansın düştüğü ve Malmquist endeksinin oldukça yoğun bir oynaklık gösterdiği şeklindedir. Politik risklerin düşük olduğu ülkelerde Malmquist endeks değerleri yüksektir. Yapılan analizlerin neticesinde makro ekonomik performans ile politik risk arasında ters yönlü bir ilişkinin olduğu sonucuna ulaşılmıştır.

Telatar ve Telatar (2004), Türkiye ekonomisini dikkate aldıkları çalışmalarında 1951 - 2001 döneminde ekonomik büyüme ile politik rejim değişikliği olasılı̆ğ arasındaki ilişkiyi probit modeliyle tahmin etmişlerdir. Çalışmada ekonomik büyüme oranından rejim değişikliğinin gerçekleşme ihtimaline yönelik negatif bir nedensellik ilişkisinin olduğu sonucu elde edilmiştir. Buna bağlı olarak ekonomik büyüme oranındaki bir düşüş, askeri müdahale üzerinden gerçekleşecek bir hükümet değişikliği ihtimalini arttırmaktadır.

Beşkaya ve Manan (2009), ekonomik özgürlüklerle demokrasinin ekonomik performans üzerindeki etkilerini 1970-2005 Türkiye örneğini dikkate alarak incelemişlerdir. Ekonomik performans göstergesi olarak büyümenin ele alındığ 1 çalışmada ekonomik özgürlüklerle ekonomik performans arasında pozitif bir ilişki bulunurken; demokrasinin, ekonomik performans üzerine etkisi konusunda kesin bir sonuca ulaşılamamıştır.

Arslan (2011), 1987-2007 dönemi Türkiye ekonomisi için yapmış olduğu çalışmada politik istikrarsızlığın ekonomik performans üzerine olan etkisini incelemiştir. Çalışmada politik istikrarsızlık verisi olarak politik istikrarsızlık endeksi, ekonomik performans göstergesi olarak da ekonomik büyüme kullanılmıştır. GSYH'dan politik istikrarsızlığa doğru bir nedensellik bulgusu elde edilmiş, politik istikrarsılılıtan GSYH'ya doğru bir nedensellik ilişkisine rastlanmamıştır. 


\section{S.ŞANLISOY -M.ÇETIN}

Özsağır (2013), çalışmasında, askeri darbe ve müdahalelerin ekonominin performans1 üzerine etkilerini 1923-2012 dönemini dikkate alarak Türkiye açısından incelemiştir. Çalışmada ekonomik performans göstergesi olarak ekonomik büyüme ele alınmış ve askeri darbe ile müdahalelerin büyüme üzerine olumsuz etkileri olduğu bulgusuna ulaşılmıştır.

Şanlısoy (2007); 1987-2006 döneminde Türkiye ekonomisinde büyüme, fiyat istikrarı, gelir dağılımı, cari işlemler dengesi ve istihdam ile politik istikrarsızlık arasındaki ilişkileri incelemiştir. Çalışmanın neticesinde politik istikrarsızlığın büyüme, fiyat istikrarı ve cari işlemler dengesi üzerinde olumsuz etkiler ortaya çıkardığı; gelir dağılımını ücret dışı gelirler lehine etkilediği; istihdam üzerinde ise olumlu etkiler ortaya çıkardığ 1 sonucuna ulaşılmıştır.

Özellikle Türkiye'ye ilişkin literatür dikkate alındığında çalışmalarda makro ekonomik performans göstergesi olarak büyümenin dikkate alındığı ifade edilebilir. Ancak daha önce de değinildiği üzere makro ekonomik performans birden fazla ekonomik değişkene bağlı olarak belirlenebilmektedir. Bu çalışmada ise birden fazla makro ekonomik değişken dikkate alınarak bir performans göstergesi oluşturulmaya çalışılarak elde edilen değişken ile politik istikrarsızlık arasındaki ilişki ortaya konulmaya çalışılmaktadır. Bu, literatüre bir katkı niteliği taşımaktadır.

\section{AMPİRIKK UYGULAMA}

Yukarıda değinilen politik istikrarsızlık kaynakları ve politik istikrarsızlıkla makro ekonomik performans arasındaki etkileşim mekanizmaları dikkate alındığında Türkiye'nin makro ekonomik performansının ve gelişmesinin önündeki en önemli engellerden birinin yaşanılan politik istikrarsızlı ortamı olduğu ifade edilebilir. Bununla beraber söz konusu değişkenlerin karşıllklı olarak birbirlerini etkileme veya ortaya çıkarma olasılıkları dikkate alındığında iki değişken arasındaki nedensellik yönünün belirlenmesi önem kazanmaktadır. Bu çalışmada da amaç nedenselliğin yönünün belirlenmesi ve buna bağlı olarak da politika önerileri getirmektir. Ayrıca bir regresyon analizinin yapılması tercih edilmemiştir. 
Çünkü oluşturulacak olan ekonomik performans göstergesinin birçok makro ekonomik değişkenden oluşmasının ve söz konusu değişkenlerin çok sayıda başka değişken tarafından belirlenmesinin modelde hem spesifikasyon hatasını hem de bir takım istatistiki sorunları beraberinde getireceği düşünülmüştür. Ayrıca amaç zaten bir katsayı tahmininde ziyade etkinin yönünü belirleyebilmektir.

\subsection{Veri Seti}

Çalışmada politik istikrarsızlık ve makro ekonomik performans değişkenleri kullanılacaktır. İlgili değişkenlere ilişkin ayrıntılı bilgilere aşağıda yer verilmiştir.

\subsubsection{Politik İstikrarsızlık Verisi}

Politik istikrarsızlık göstergeleri, bileşiminde öne çıkan faktörlere bağlı olarak iki farklı kategoride ele alınabilir (Brunetti, 2006:122-123).

- Politik şiddetin ölçülmesi ve

- Hükümet değişikliklerinin ölçülmesi

Yukarıdaki öğeler dikkate alınarak politik istikrarsızlığa ilişkin göstergeler gerek araştırmacılar gerekse kurumlar tarafından oluşturulmaktadır. Örneğin Türkiye'ye ilişkin Telatar ve Cangir (2014) ve Demirgil (2011) kendi endekslerini oluşturmuşlar ayrıca çalışmalarında tutarlı sonuçlar da elde etmişlerdir.

Kurumlar tarafından oluşturulan endekslere örnek olarak bu çalışmada da tercih edilen Politik Risk Grubu (PRS Group) tarafindan hazırlanan "Uluslararası Ülke Risk Rehberi” (ICRG-International Country Risk Guide)'nden alınan “Politik Risk Endeksi" verilebilir. Bu endeks; hükümet istikrarı, sosyo-ekonomik koşullar, yatırım profili, içsel çatışmalar, dişsal çatışmalar, yolsuzluk, politik alanda askerin etkisi, politik alanda dinin etkisi, yasal düzenlemeler, etnik gerilimler, demokratik şeffaflık ve bürokrasi kalitesi olmak üzere 12 alt bileşenden oluşmaktadır (PRS, Yı1 Belirtilmemiş: 3). Söz konusu endeks, Alesina ve Weder (1999:9)'de ortaya konulduğu üzere literatürde en sık kullanılan endeks olduğundan tercih edilmiştir. Endeksin literatürde sıklıkla kullanılmasının nedeni; en uzun zaman diliminde, en fazla ülke sayısına yer veren ve çok farklı alt bileşenleri içeren bir endeks 


\section{S.ŞANLISOY -M.ÇETIN}

olmasıdır. Bu durum Türkiye örneği ile de uyumludur. Daha önce de ifade edildiği üzere Türkiye'de politik istikrarsızlı̆̆ın farklı kaynaklardan beslenmesi bu endeksi daha anlamlı hale getirmektedir.

\subsubsection{Makro Ekonomik Performans Verisi}

Hükümet performanslarının ölçülmesine ilişkin literatür incelendiğinde, ölçümün gerek doğrudan ekonomik göstergeler gerekse sosyal göstergeler kullanılarak yapıldığ1 görülmektedir. Bu bakımdan Türkiye'ye ilişkin literatürü şekillendiren temel unsur veri kısıtı olmuştur. Bu çerçevede hem birbirini takip eden hükümet dönemlerine ilişkin hem de tekil hükümetlerin performanslarının ölçülmesine yönelik çalışmalar bulunmaktadır. Uluslararası literatürde ise performansın ölçülmesinde etkinliğin arttırılması yapılan çalışmaların odak noktasını oluşturmaktadır. Geliştirilen endeksler ve parametrik olmayan yöntemler performans ölçümlerinin temel aracı olmuşlardır. Türkiye ekonomisini dikkate alan bazı makro ekonomik performans göstergesi hesaplamalarına yönelik çalışmalara ilişkin bilgilere aşağıda kısaca yer verilmiştir. Söz konusu çalışmalarda amaç, ele alınan dönemler açısından makro ekonomik performansları kıyaslamak olmuştur.

Telatar (2000), çalışmasında Türkiye'deki farklı hükümet dönemlerini değerlendirmiştir. Bunun için Okun tipi, Barro tipi ve Yeniden Düzenlenmiş Endeksleri kullanmıştır. 1950 - 60 dönemindeki Menderes hükümetleri, 1961 - 65 dönemindeki İnönü hükümetleri, 1965 - 71 dönemindeki Demirel hükümetleri, 1983 - 91 dönemindeki Özal hükümetleri ve Çiller (DYP-CHP koalisyonu) dönemleri üç endeks için de ayrı ayrı ayrıca test edilmiş ve analizin neticesinde Okun tipi ve Yeni Düzenlenmiş Endeks için İnönü hükümetlerinin en başarılı hükümetler ve Çiller hükümetlerininse en başarısız hükümetler olduğu bulgusuna ulaşılmıştır.

Güran ve Tosun (2005) çalışmalarında ekonomik büyüme, enflasyon oranı, işsizlik oranı ve cari işlemler açığı olmak üzere dört değişkeni tek bir değişkenle ifade ederek Türkiye'nin 1951-2003 dönemini makro ekonomik performans açısından analiz etmişlerdir. Veri zarflama analizi (VZA) yöntemi kullanılarak 
makro ekonomik performans ile ihtilaller arasındaki etkileşimin varlığ $\operatorname{araştırılmış~}$ ancak net bir bulguya ulaşılamamıştır.

Kibritçioğlu (2007) de analizlerinde endeksleri kullanmıştır. Çalışmada 1987 2007 dönemi farklı makro ekonomik performans endeksleri ile değerlendirilmiş ve RP-DYP hükümetinin en başarıl1; 1993-1996 döneminde iktidarda olan DYP-SHP, DYP ve DYP-CHP hükümetlerinin ise en başarısız hükümetler olduğu sonucuna ulaşı1mıştır.

Eleren ve Karagül (2008), çok kriterli karar verme yöntemini kullanarak 1980 2006 dönemindeki hükümet performanslarını analiz etmiştir. Çalışmada ekonomik büyüme, cari açık, enflasyon, işsizlik ve kamu borç faiz oranı değişkenleri kullanılmıştır. Yıl bazında hesaplanan başarı puanlarının elde edildiği çalışmada 1986, 1990, 1987 ve 1993 y1llarının en başarıl1; 1999, 2001, 2006 ve 2000 yıllarınınsa en başarısız yıllar olduğu sonucuna ulaşılmıştır.

Kaynak ve Balcı (2009), parasal ve parasal olmayan değişkenlere yer verdikleri çalışmalarında Türkiye'deki hükümetlerin performanslarını analiz etmiştir. Çalışmada faktör analizi yöntemi kullanılarak 1923 - 2007 dönemi test edilmiştir. Yapılan analizlerin neticesinde uzun süreli tek parti iktidarlarının kısa ömürlü tek parti ve koalisyon hükümetlerinden daha yüksek bir başarı sergiledikleri belirlenmiştir.

Şanlısoy ve Çetin (2016) 1950 - 2015 döneminde Türkiye ekonomisinin makro ekonomik performansı farklı açılardan değerlendirerek karşılaştırmışlardır. Ekonomik süreç politikası amaçlarını ifade eden değişkenler farklı ağırlıklarla kullanılarak farklı makro ekonomik performans endeksleri elde edilmiştir. Söz konusu endeksler dikkate alındığında tek parti iktidarlarının diğer hükümet tiplerinden daha iyi bir performans gösterdiği, ayrıca dışa açık ekonomiye geçiş döneminin en başarılı dönem olduğu bulguları elde edilmiştir.

$\mathrm{Bu}$ çalışmada hükümet performanslarına ilişkin olarak ağırlıklandırılmış bir endeks oluşturmak amacıyla öncelikle hükümet performanslarının iktisadi alandaki belirleyenleri tespit edilmiştir. Bunun için de ekonomik süreç politikası 


\section{S.ŞANLISOY -M.ÇETIN}

amaçlarından hareketle ekonomik büyüme, enflasyon, faiz oranı, işsizlik, kamu dış borç stoku, bütçe açığı ve cari açık değişkenleri tercih edilerek kullanılmıştır. Seçilen değişkenlere ilişkin veriler, Türkiye Cumhuriyet Merkez Bankası EVDS veri tabanından, Kalkınma Bakanlığı'nın resmi internet sitesinden, Türkiye İstatistik Kurumu İstatistik Göstergeler yayınından, Maliye Bakanlığı'na bağlı Muhasebat Genel Müdürlügü̈'nden ve Hazine Müsteşarlığı'ndan elde edilmiştir. Büyüme ve enflasyon verileri baz yılı 1968 olmak üzere sabit fiyatları ile alınmışken, Net Kamu Dış Borç Stoku yüzde değişim olarak hesaplanmıştır. Faiz oranı kredi ve para arzında meydana gelen genişlemelerin hesaba katılabilmesi için Merkez Bankası'nın kısa vadeli reeskont faiz oranı olarak kullanılmıştır. Cari açık ve bütçe açığı değişkenleri ise GSMH'ye oranları cinsinden ifade edilmiştir.

Ağırlıklandırılmış performans verilerinin elde edilmesinde Hwang ve Yoon (1981) tarafindan geliştirilen TOPSIS yönteminin çözüm aşamalarından faydalanılmıştır. $\mathrm{Bu}$ aşamalar çerçevesinde belirlenen ağırlıklara bağlı olarak normalize ve ağırlıklandırılmış normalize karar matrisleri oluşturulmuş, pozitif ve negatif ideal çözümler belirlenerek; ideal çözüm noktasına olan uzaklıklar hesaplanmıştır. İdeal çözüme göreli yakınlıkların hesaplanması neticesinde performans değerleri oluşturulmuştur. TOPSİS yönteminde dikkate alınan kriterlerin önem dereceleri birbirinden farklı olabilir. Buna bağlı olarak kriterlerin ağırlıklandırılmasında ele alınan problemin niteliğine bağlı olarak, farklı teknikler kullanılabilir. Bu tekniklerin bazıları; analitik hiyerarşi süreci (AHP), analitik ağ süreci (ANP), eigen vektör ve entropi gibi tekniklerdir (Chu, 2007: 1015).

$\mathrm{Bu}$ çalışmada kriterlerin ağırlıklandırılmasında ${ }^{3}$ analitik ağ süreci (ANP) tekniği kullanılarak elde edilen ağırlıklar kullanılmıştır. ANP ağırlıklarının elde edilmesinde Super Decisions programı kullanılmıştır. AHP'nin temel esasları ve

\footnotetext{
${ }^{3}$ Çalışmada iki ağırlıklandırma yöntemi daha kullanılmıştır. Birincisinde her bir kriterin eşdeğer ağırlığa sahip olduğu varsayılmıştır. İkincisinde Kirschen vd. (1967; Aktaran Erkan, 2000: 157) tarafindan iktidardaki partilerin sosyal demokrat, merkez ve muhafazakar kimliğine göre belirlenmiş amaçların ordinal sıralaması dikkate alınarak Maskin (2008) tarafından geliştirilen "mekanizma tasarımı" ile ordinal sıralamanın kardinal hale getirilmesiyle belirlenen ağırlıklandırma kullanılmıştır. Her iki ağırlıklandırmaya göre oluşturulan performans göstergeleri ile politik istikrarsızlık arasında istatistiki olarak anlamlı sonuca ulaşılamadığından sonuçlara burada yer verilmemiş̧ir.
} 
Dokuz Eylül Üniversitesi İktisadi ve İdari Bilimler Fakültesi Dergisi Cilt:32, Sayl:2, Yll:2017, ss. 207-237

ikili karşılaştırma mantığı ANP yönteminde de geçerlidir. Ancak AHP, karar düzeyleri arasında tek yönlü bir hiyerarşik ilişkinin varlığı durumunda tercih edilirken; ANP, karar düzeyleri arasında kompleks karşılıklı ilişkilerin bulunması durumunda analiz yapılmasına olanak sağladığından bu çalışmada da tercih edilmiştir. (Yüksel ve Dağdeviren, 2007: 3364).

Tablo 1: Değerlendirme Kriterlerinin Ağırlık Değerleri

\begin{tabular}{|l|l|}
\hline Kriterler & ANP Ağırlıkları \\
\hline Büyüme & 0,3768475 \\
\hline İşsizlik & 0,1365627 \\
\hline Enflasyon & 0,1339627 \\
\hline Faiz Oranı & 0,1902638 \\
\hline Dış Borç & 0,0826817 \\
\hline Cari Açık & 0,0489010 \\
\hline Bütçe Açı̆̆ı & 0,0307806 \\
\hline Toplam & 1 \\
\hline
\end{tabular}

Değişkenler 1984-2015 dönemini içermektedir. Veriler yıllık olarak alınmış ve logaritmik formları kullanılmıştır. Değişkenlere ilişkin özet bilgiler Tablo 2'de gösterilmiştir.

Tablo 2. Değişkenlere İlişkin Bilgiler

\begin{tabular}{|l|l|l|l|}
\hline \multicolumn{1}{|c|}{ Değişken } & Kısaltma & \multicolumn{1}{c|}{ Kaynak } & \multicolumn{1}{c|}{ Tanımlama } \\
\hline $\begin{array}{l}\text { Politik } \\
\text { İstikrarsızlık }\end{array}$ & LPRI & PRS Group & Politik istikrarsızlık endeksinin logaritması \\
\hline $\begin{array}{l}\text { Makro Ekonomik } \\
\text { Performans } \\
\text { Göstergesi }\end{array}$ & LANP & $\begin{array}{l}\text { Kendi } \\
\text { Hesaplamamız }\end{array}$ & $\begin{array}{l}\text { ANP ağırlıklandırılmasına göre elde edilen } \\
\text { değerin logaritması }\end{array}$ \\
\hline
\end{tabular}




\subsection{Yöntem}

\section{S.ŞANLISOY -M.ÇETİN}

İki değişken arasında zamana bağlı olarak bir neden sonuç ilişkisinin bulunup bulunmadığının araştırılması nedensellik analizi olarak adlandırılmaktadır. Değişkenler arasındaki nedensellik ilişkilerinin, Granger (1969) tarafından geliştirilen nedensellik testi ile beraber analiz edilmeye başlandığı görülmektedir. Rastsal bir X değişkeninin geçmişi, bütün olası ilgili diğer etkenler ve rastsal olmayan bilgiler de dikkate alındıktan sonra, diğer bir rastsal Y değişkeninin geleceğinin daha iyi tahmin edilmesini sağliyorsa, "X değişkeni $Y$ 'nin Granger nedenidir" denir (Atukeren, 2011: 137-138).

Klasik regresyon analizi, zaman serisi değişkenlerini durağan, kabul etmektedir (Gujarati, 2006: 713). Buna rağmen zaman serilerinin durağanlık düzeyleri incelendiğinde makro ekonomik serilerin büyük çoğunluğunun düzeyde durağan olmadığı belirlenmiştir. Durağan olmayan zaman serileri kullanıldıkları ekonometrik uygulamalarda bağımlı ve bağımsız değişkenler arasında sahte regresyon ilişkisine neden olabilmektedir. Bu durum elde edilen bulguların yanlış çıkmasına sebep olabilmektedir. Dolayısıyla Granger nedensellik testinin yapılabilmesi için her iki değişkenin de kovaryans-durağan ve stokastik olması gerekmektedir. $\mathrm{Bu}$ çalışmada değişkenler arasında nedensellik ilişkisinin belirlenebilmesi için Granger nedensellik analizi tercih edilmiştir. Granger nedensellik testinin standart yöntemi aşağıdaki denklemlerin en küçük kareler yöntemiyle tahminini gerektirmektedir.

$$
\begin{aligned}
& Y_{t}=\sum_{i=1}^{m} \alpha_{i} Y_{t-i}+\sum_{i=1}^{m} \beta_{i} X_{t-i}+u_{1 t} \\
& X=\sum_{i=1}^{m} \theta_{i} X_{t-i}+\sum_{i=1}^{m} \gamma_{i} Y_{t-i}+u_{2 t}
\end{aligned}
$$

Burada $\mathrm{m}$ gecikme uzunluğunu göstermektedir, u1t ve u2t hata terimlerinin birbirinden bağımsız oldukları varsayılmaktadır. "X, Y'nin Granger nedeni değildir” şeklinde H0 hipotezi sınanır ve boş hipotez kabul edilmezse " $\mathrm{X}$, Y'nin nedenidir hipotezi" kabul edilir. 


\subsection{Ampirik Bulgular}

Çalışmanın amacı doğrultusunda açıklanan ekonometrik analiz yöntemleri kullanılarak elde edilen sonuçlara aşağıda yer verilmiştir.

\subsubsection{Birim Kök Testi Sonuçları}

Yukarıda da değinildiği üzere Granger nedensellik testinin gerçekleştirilmesinde değişkenlerin durağanlıklarını araştırmak gerekmektedir. $\mathrm{Bu}$ amaçla ADF (Genişletilmiş Dickey-Fuller) ve Phillips-Perron Testleri ile serilerin durağanlık düzeyleri belirlenmiş ve sonuçları Tablo 3 ve Tablo 4 'te verilmiştir.

Tablo 3. ADF ve PP Birim Kök Testleri (Sabitli ve Trendsiz)

\begin{tabular}{|l|c|c|c|c|c|}
\hline \multirow{2}{*}{ Değişken Adı } & \multicolumn{2}{|c|}{ ADF } & \multicolumn{2}{c|}{ PP } & \\
\hline Lüzey & $\begin{array}{c}\text { 1. Farklar } \\
\text { Test } \\
\text { İstatistiği }\end{array}$ & Düzey & $\begin{array}{c}\text { 1. Farklar } \\
\text { Test } \\
\text { İstatistiği }\end{array}$ & Sonuç \\
\hline LANP & $-2,977504$ & $-4,209611$ & $-2,317068$ & $-4,385931$ & I(1) \\
\hline $\begin{array}{l}\text { Mac Kinnon Kritik Değeri } \\
\text { Test İstatistiği (\%5) }\end{array}$ & -2.963972 & -2.963972 & -2.960411 & -2.963972 & \\
\hline
\end{tabular}

Tablo 4. ADF Birim Kök Testi (Sabitli ve Trendli)

\begin{tabular}{|l|c|c|c|c|c|}
\hline & \multicolumn{2}{|c|}{ ADF } & \multicolumn{2}{c|}{ PP } & \\
\cline { 1 - 5 } Değişken Adı & $\begin{array}{c}\text { Düzey } \\
\text { Test } \\
\text { İstatistiği }\end{array}$ & $\begin{array}{c}\text { 1. Farklar } \\
\text { Test } \\
\text { İstatistiği }\end{array}$ & Düzey & $\begin{array}{c}\text { 1. Farklar } \\
\text { Test } \\
\text { İstatistiği }\end{array}$ & Sonuç \\
\hline LPRI & $-3,002634$ & $-4,154794$ & $-2,308351$ & $-4,613553$ & I(1) \\
\hline LANP & $-3,225920$ & $-4,254332$ & $-3,213888$ & $-7,006843$ & I(1) \\
\hline $\begin{array}{l}\text { Mac Kinnon Kritik Değeri } \\
\text { Test İstatistiği (\%5) }\end{array}$ & -3.568379 & -3.568379 & -3.562882 & -3.568379 & \\
\hline
\end{tabular}




\section{S.ŞANLISOY -M.ÇETİN}

Tablo 3 incelendiğinde sabitli ve trendsiz ADF ve PP birim kök testlerinin sonuçlarına göre LANP değişkenin düzeyde durağan olduğu, ancak aynı değişkenin sabitli ve trendli ADF ve PP birim kök testlerinin sonuçlarına göre I(1) olduğu sonucuna ulaşılmıştır. LPRI değişkenine ilişkin sonuçlar değerlendirildiğinde ise sabitli ve trendsiz durumda ADF testine göre düzeyde durağan, PP testine göre ise I(1) olduğu görülmektedir. Söz konusu değişken sabitli ve trendli test sonuçlarına göre ise I(1) olarak görülmektedir.

Standart birim kök testlerinin önemli bir eksikliği yapısal kırılmaları dikkate almamalarıdır. Ancak iktisadi zaman serileri, özellikle yaşanan bunalım dönemlerinin etkisiyle, genellikle kırılmalara maruz kalmaktadır. Yapısal kırılmaların varlığı durumunda bu kırılmaları dikkate almayan standart birim kök testlerinin gücü azalmaktadır. Gerek yapısal kırılmaların ADF ve PP testlerinin güçlerini zayıflatması gerekse bu testlere göre serilerin durağanlıklarına ilişkin kesin bulgulara ulaşılamaması nedeniyle çalışmada kırılmayı dikkate alan ZivotAndrews birim kök testi kullanılmıştır (Zivot ve Andrews, 1992).

Zivot-Andrews birim kök testinin önemli özelliklerinden biri kırılma yıllarını içsel olarak belirlemesidir. Birim kökün varlığını ifade eden boş hipotez, "kırılmanın varlığı durumunda değişken durağandır" şeklindeki alternatif hipoteze karşı test edilmektedir. Test istatistiğinin alternatif önem düzeylerindeki kritik değerden küçük olması durumunda boş hipotez reddedilmekte, alternatif hipotez kabul edilmektedir (Kök vd., 2015: 159).

Tablo 5: Tek Kırılmalı Zivot-Andrews Birim Kök Testi

\begin{tabular}{|c|c|c|c|c|}
\hline Değişkenler & \multicolumn{2}{|c|}{ Model A } & \multicolumn{2}{|c|}{ Model C } \\
\hline LPRI & $-3,638216$ & 1992(1) & $-4,138608$ & 2004(1) \\
\hline LANP & $-4,434211$ & $2005(0)$ & $-4,521292$ & 1999(0) \\
\hline \multicolumn{5}{|c|}{ Kritik Değerler } \\
\hline & \multicolumn{2}{|c|}{$\% 1$} & $\% 5$ & $\% 10$ \\
\hline Model A & \multicolumn{2}{|c|}{$-5,34$} & $-4,83$ & $-4,58$ \\
\hline
\end{tabular}


Dokuz Eylül Üniversitesi İktisadi ve İdari Bilimler Fakültesi Dergisi

Cilt:32, Sayl:2, Yll:2017, ss. 207-237

\begin{tabular}{|c|c|c|c|}
\hline Model Bilgi & $-5,57$ & $-5,08$ & $-4,82$ \\
\hline
\end{tabular}

Zivot-Andrews Birim Kök Testi sonuçları incelendiğinde serilerin birim kök içerdiği, bir başka ifadeyle düzeyde durağan olmadıkları sonucuna ulaşılmıştır.

\subsubsection{Granger Nedensellik Testi Sonuçları}

Analiz yapılırken ilk olarak değişkenlerin ADF ve PP bütünleşme testleri yardımıyla durağanlık düzeyleri belirlenmiştir. Değişkenlerin aynı düzeyde durağan olmaları Granger nedensellik testinin kullanılabilmesine olanak sağlamıştır. Granger nedensellik testinin bulguları Tablo 6'da gösterilmektedir.

Tablo 6: Granger Nedensellik Testi Sonuçları

\begin{tabular}{|l|c|c|}
\hline \multicolumn{1}{|c|}{ Ho } & Test İstatistiği & Olasılık \\
\hline $\begin{array}{l}\text { DLPRI, DLANP'nin Granger nedeni } \\
\text { değildir. }\end{array}$ & 6,802230 & 0,0333 \\
\hline $\begin{array}{l}\text { DLANP, DLPRI'nin Granger nedeni } \\
\text { değildir. }\end{array}$ & 2,324755 & 0,3128 \\
\hline
\end{tabular}

Nedensellik testi sonuçlarına göre büyüme ile politik istikrarsızlık arasında tek yönlü bir nedensellik ilişkisinin olduğu bulgusuna ulaşılmıştır. Dolayısıyla politik istikrarsızlıktan makro ekonomik performansa doğru bir nedensellik ilişkisi söz konusudur. Başka bir ifadeyle politik istikrarsızlık makro ekonomik performansın Granger nedenidir. Granger nedensellik testi değişkenler arasında nedensellik ilişkisinin varlığına ilişkin bilgi vermekle birlikte değişkenlerden birinde meydana gelen değişimin diğerini aynı yönde mi yoksa ters yönde mi etkilediği konusunda bilgi vermemektedir. Çalışmada değişkenler arasındaki söz konusu ilişkinin yönünü belirleyebilmek amacıyla hata düzeltme modeli kullanılmış ve ilişkinin ters yönlü olduğu sonucuna ulaşılmıştır. Dolayısıyla politik istikrarsızlıktaki artış makro ekonomik performansı düşürmektedir.

\section{SONUÇ VE POLITIKA ÖNERILERİ}

$\mathrm{Bu}$ çalışmada 1984 - 2015 döneminde Türkiye ekonomisinde politik istikrarsızlık ve makro ekonomik performans arasındaki ilişki nedensellik analizi 


\section{S.ŞANLISOY -M.ÇETIN}

ile incelenmiştir. Çalışmanın bulguları değerlendirildiğinde literatürle uyumlu bir şekilde politik istikrasızlıkla büyüme arasında bir nedensellik ilişkisinin bulunduğu görülmektedir. Söz konusu nedensellik ilişkisini Türkiye ekonomisi için analiz eden ve makro ekonomik performans göstergesi olarak ekonomik büyümeyi dikkate alan çalışmalarda nedensellik ilişkisinin yönünün ekonomik büyümeden politik istikrarsızlığa doğru olduğu sonucuna ulaşılmaktadır. Bu çalışmada ise nedensellik ilişkisinin politik istikrarsızlıktan makro ekonomik performansa doğru olduğu sonucuna ulaşılmıştır. Böyle bir sonuca ulaşılmasında makro ekonomik performans değişkeninin içerisinde ekonomik büyüme değişkenine ilave olarak diğer temel makro ekonomik değişkenlerin bulunmasının etkili olduğu ifade edilebilir.

Çalışmada elde edilen bulgulardan hareketle Türkiye özelinde politik istikrara doğru bir ilerleme sağlanması durumunda ülkenin makro ekonomik performansında da gelişmelerin sağlanabileceği ifade edilebilir. Ancak Türkiye'nin yaşadığı politik istikrarsızlıklar sadece yurtiçi politik değişimlerden kaynaklanmamakta; özellikle komşu ülkeler olmak üzere diğer ülkelerle olan ilişkilerden ya da komşu ülkelerin kendi iç karışıklıklardan da kaynaklanmaktadır. Devletin gerek DAEŞ, gerekse PKK/PYD-YPG terör örgütlerine yönelik politikalarındaki kararlılığın vurgulanmasıyla bu konuda uluslararası alanda müttefikler kazanılmalıdır.

Türkiye'de politik alanın iç dinamiklerine bağlı olarak ortaya çıkan politik istikrarsızlıklar dikkate alındığında özellikle 1990'lı yıllardaki koalisyon hükümetlerinin ardından 2002 y1lından sonra tek parti hükümetinin iktidara gelmesinin bir sonucu olarak göreceli bir politik istikrarın sağlandığı ifade edilebilir. Ancak 2000'li yılların sonlarına doğru ortaya çıkan süreçte politik kutuplaşmanın ve toplumsal ayrışmanın yoğunlaşmasının orta ve uzun dönemde potansiyel bir istikrarsızlık beklentisini de beraberinde getirdiği ifade edilebilir.

Politik istikrarsızlığı ortaya çıkaran iç unsurların gerekli hukuksal düzenlemelerle çözümlenmesine, demokrasi ve uzlaşma kültürünün toplumda içselleştirilmesine ihtiyaç duyulmaktadır. Bu noktaların dikkate alınmasıyla politik 
alanda gerçekleştirilecek atılımlar, ülkenin makro ekonomik performansını artırarak; sosyal refahın yükselmesini ve uluslararası arenada daha güçlü ve gelişmiş bir Türkiye'nin varlığını belirgin bir şekilde hissettirmesini sağlayacaktır. Ülkenin uluslararası arenada güç kazanması, yurtdışı kaynaklı politik istikrarsızlıktan kaynaklanan sorunların çözümünde de etkili olacaktır.

Ancak unutulmamalıdır ki politik istikrarsızlık sorunlarının çözülmesi, çok sayıda faktör tarafindan belirlenen makro ekonomik performansın arttırılmasında etkili tek faktör değildir. Türkiye ekonomisinin yapısal koşulları dikkate alındığında ithal girdi bağımlılığı, finansal yatırımlara dayalı büyüme, yabancı finansal sermaye akışları gibi yapısal sorunlar da politik istikrara rağmen ekonomik istikrarsızlığa yol açabilmektedir. Nitekim küreselleşme sürecinin kendisi küresel krizlerin yabancı sermaye bağımlılı̆ğ üzerinden gelişmekte olan ülkelere aktarılmasını kolaylaştırmıştır. Herhangi bir ülkenin finansal piyasalarında yaşanan istikrarsızlıklar belirli kanallar üzerinden diğer ülkelere sıçrayıp domino etkisi yaratabilmektedir. Söz konusu istikrarsızlık kaynaklarını bertaraf edebilmek için yurtiçi tasarrufların artması sağlanmalı, sabit sermaye yatırımları arttırılmalı, cari açık azaltılmalı ve kamu kaynakları iktisadi açıdan daha etkin alanlara kaydırılmalıdır. Finans sektörünün reel sektör ile birleşmesi sağlanarak; finansal araçlarda meydana gelen spekülatif fiyatlama hareketlerinin istikrarsızlık yaratıcı etkileri ortadan kaldırılmalıdır.

Dolayısıyla ekonomik alanda özellikle teknolojik yeniliklerin yaratılmasına imkan sağlayacak mekanizmalar oluşturularak; dış kaynak bağımlılığın azaltılması, bilgi işçilerinin yetiştirilmesine yönelik eğitim politikalarının oluşturulması ve yenilenmesi önemlidir. Bütün bunlar reel dinamiklere dayalı kalıcı bir ekonomik büyümeyi ve karşılıklı etkileşim ilişkisi dikkate alındığında politik istikrarı beraberinde getirecektir. Böylece Türkiye, ortalama refah seviyesi daha yüksek, gerek ekonomik gerekse politik açıdan daha güçlü, dolayısıyla uluslararası arenada lider bir ülke konumuna gelebilir. 


\section{KAYNAKÇA}

\section{S.ŞANLISOY -M.ÇETİN}

AHMED, M. U., PULOK, M. H. (2013), "The Role of Political Stability on Economic Performance: The Case Of Bangladesh", Journal of Economic Cooperation \& Development, 34 (3), 61-99.

ALESINA, A., PEROTTI, R. (1993), "Income Distribution, Political Instability, and Investment", NBER Working Paper, No. w4486, 1-33.

ALESINA, A., ÖZLER, S., ROUBINI, N., SWAGEL, P. (1996), "Political Stability and Economic Growth", Journal of Economic Growth, 1(2), 189-21.

ALESINA, A., WEDER, B. (1999), "Do Corrupt Governments Receive Less Foreign Aid", NBER Working Paper Series, No. 7108, Cambridge, 1-42.

ARSLAN, Ü. (2011), "Siyasi İstikrarsızlı ve Ekonomik Performans: Türkiye Örneği”, Ege Academic Review, 11(1), 73-80.

ASTERIOU, D., PRICE, S. (2001), "Political Instability and Economic Growth: UK Time Series Evidence", Scottish Journal of Political Economy, 48 (4), 383399.

ATUKEREN, E. (2011), "Granger-Nedensellik Sınamalarına Yeni Yaklaşımlar", Atatürk Üniveristesi. İ̈BF Dergisi, 10. Ekonometri ve İstatistik Sempozyumu Özel Sayıs1, 137-153.

BERTHÉLEMY, J., KAUFFMANN, C., RENARD, L., WEGNER, L. (2000), "Political Instability, Political Regimes and Economic Performance in African Countries", Draft Paper for African Economic Outlook, Paris, 1-23.

BEŞKAYA, A., MANAN, Ö. (2009), "Ekonomik Özgürlükler ve Demokrasi ile Ekonomik Performans Arasındaki İlişkinin Zaman Serileri ile Analizi: Türkiye Örneği”, ZKÜ Sosyal Bilimler Dergisi, Cilt 5, Sayı 10, 47-76.

BIENEN, H.S., LONDREGAN, J., NICHOLAS, V. W. (1993), Ethnicity, Leadership Succession, and Economic Development in Africa, Institute for Policy Reform, Washington, D.C. 
BREUSS, F., LUPTACIK, M., MAHLBERG, B. (2000), "How far away are the CEECs from the EU Economic Standards? A Data Envelopment Analysis of the Economic Performance of the CEECs", IEF Working Paper, Nr. 35, 2-38.

BRUNETTI, A., (2006), "Political Variables in Growth Regressions", Volatility, Uncertainty, Instability and Growth, 117-135.

BUTKIEWICZ, J. L., YANIKKAYA, H. (2005), "Time-Consistent Polities and Growth in Developing Countries: An Empirical Analysis", Working Papers 0502, University of Delaware, Department of Economics, 1-25.

CAMPOS, N. F., NUGENT, J.B. (2002), "Who is Afraid of Political Instability", Journal of Development Economics, 67(1), 157-172.

CHU, M. (2007), "Comparison Among Three Analytical Methods for Knowledge Communities Group Decision Analysis", Expert Systems with Aplications, 33, 1011-1024.

DE HAAN, J., SIERMANN, C. L. J. (1996), "Political Instability, Freedom, and Economic Growth: Some Further Evidence", Economic Development and Cultural Change, 44(2), 339-350.

ELEREN, A., KARAGÜL, M. (2008), “1986-2006 Türkiye Ekonomisinin Performans Değerlendirmesi”, Yönetim ve Ekonomi, 15(1), 1-14.

EREN, E., BİLDİİCI, M. (2001), Türkiye'de Siyasal ve İktisadi İstikrarsızlı; 1980-2001, İktisat, İşletme ve Finans, Y11:16, Say1:187, 27-43.

ERKAN, H. (2000), Ekonomi Politikasının Temelleri, 4. Bask1, İlkem Ofset, İzmir.

FIELDING, D. (2003), "Modelling Political Instability and Economic Performance: Israel Investment During the Intifada", Economica, 70, 159-186.

GRANGER, C. W. J., NEWBOLD, P. (1974), "Spurious Regressions in Econometrics", Journal of Econometrics, 2, 111-120. 


\section{S.ŞANLISOY -M.ÇETIN}

GUJARATI, D. (2006), Temel Ekonometri, Çev. Ümit Şenesen ve Gülay Günlük Şenesen, Literatür Yayıncılık, İstanbul.

GÜRAN, M.C., TOSUN, M.U. (2005), "Türkiye Ekonomisinin Makro Ekonomik Performansı: 1951-2003 Dönemi İçin Parametrik Olmayan Bir Ölçüm”, Ankara Üniversitesi SBF Dergisi, 60 (4), 89-115.

HABER, S., RAZO, A. (1998), "Political Instability and Economic Performance: Evidence from Revolutionary Mexico", World Politics, 51()1, 99-143.

İSMIHAN, M., KIVILCIM, M. Ö., TANSEL, A. (2002), "Macroeconomic Instability, Capital Accumulation and Growth: The Case of Turkey 1963-1999", Bilkent University Working Paper, 1-28.

KARAHAN, H., KARAGÖL, E. T. (2014), “Ekonomik Performansın Temel Taşı: Siyasi İstikrar", Seta Perspektif, 41, 1-5.

KAYNAK, M., BALCI, Ö. (2009), "Kalkınma Performansları Açısından Cumhuriyet Hükümetleri: 1923 - 2007”, 11. Sosyal Bilimler Kongresi, 9-11 Aralık 2009, Ankara.

KIBBRITÇi̇ĞLU, A. (2007), A Comparison of Macroeconomic Performances of Governments in Turkey 1987-2007, http://mpra.ub.uni - muenchen.de /3962/1/ MPRA_paper_3962.pdf, 21.07.2015.

KIRMANOĞLU, H. (2003), "Political Freedom and Economic Well-Being: A Causality Analysis", ECOMOD Annual Meeting, July 2003, Istanbul, Turkey.

KÖK, R., EKİNCİ, R., YALÇINKAYA, E. A. (2015), "Ülke Riski Bileşenlerinin Bankacılık ve Reel Sektör Üzerine Etkileri: Türkiye Örneği, 1993-2015”, Çukurova Üniversitesi İIBF Dergisi, 19(2), 151-171.

LONDREGAN, J. B., POOLE, K. (1990), "Poverty, The Coup Trap, and the Seizure of Executive Power", World Politics, 42(2), 151-183. 
MASKIN, E.S. (2008), "Mechanism Design: How to Implement Social Goals", American Economic Review, 98(3), 567-576.

MOHAMAD, N. (2007), A Linear Programming Formulation of Macroeconomic Performance: The Case of Asia Pacific, Matematika, 23(1), 29-40.

OLSON, M. (1982), The Rise and Decline of Nations: Economic Growth, Stagflation and Social Rigidities, New Hawen, Yale University Press.

OLSON, M. (1991), Autocracy, Democracy and Prosperity, Strategy and Choice, MIT Press, Cambridge, 131-157.

ÖZSAĞIR, A. (2013), “Askeri Darbe ve Müdahalelerin Ekonomik Performans Üzerine Etkisi: Türkiye Örneği”, University of Gaziantep Journal of Social Sciences, 12(4), 759-773.

PARLAKYILDIZ, M. (2015), "Makro Ekonomik ve Politik İstikrarsızlığın Ekonomik Performans Üzerine Etkisi: Latin Amerika Örneği". Çukurova Üniversitesi İIBBF Dergisi, 19(2), 1-11.

The PRS Group, ICRG Methodology, http://www.prsgroup.com/wpcontent/uploads /2012/11/icrgmethodology.pdf, (28.08.2015)

SAKAMOTO, T. (2005), "Economic Performance of 'Weak' Governments and Their Interaction with Central Banks and Labour: Deficits, Economic Growth, Unemployment and Inflation, 1961-1998", European Journal of Political Research, 44(6), 801-836.

ŞANLISOY, S. (2007), Ekonomi-Politika Etkileşiminin Süreç Politikası Açısından Analizi: Türkiye Örneği, Dokuz Eylül Üniversitesi, Sosyal Bilimler Enstitüsü, Yayınlanmamış Doktora Tezi.

ŞANLISOY, S. (2010), "Politik İstikrarsızlık-Ekonomik Süreç Politikaları Etkileşimi”, Sosyo Ekonomi, Y11:6, Sayı:13(2), 191-214. 


\section{S.ŞANLISOY -M.ÇETIN}

ŞANLISOY, S., KÖK, R.(2010), "Politik İstikrarsızlık - Ekonomik Büyüme İlişkisi: Türkiye Örneği (1987-2006)", Dokuz Eylül Üniversitesi İIBF Dergisi, 25(1), 101-125.

ŞANLISOY, S., ÇETIN, M. (2016), "Türkiye Ekonomisinde Hükümet Performanslarının TOPSIS Yöntemi İle Ölçülmesi”, Sosyoekonomi, 24(28), 6584.

TELATAR, F. (2000), "Makro Ekonomik Performans İndekslerine Göre Hükümetler Arası Sıralamalar 1950-1996”, İktisat, İşletme ve Finans, 15(175), 55-69.

TELATAR, F. (2003), “Türkiye'de Politika Değişkenliği ile Ekonomik Büyüme Arasındaki Nedensellik İlişkileri”, İktisat İşletme ve Finans, 18(211), 71-91.

TELATAR, E., TELATAR, F. (2004), "Standart IMF İstikrar Politikaları: Politik İstikrarsızlığa Yol Açan Bir Kanal”, İktisat, İşletme ve Finans, 19(215), 53-65.

TElATAR, E., CANGİR, N. (2014), "Türkiye İçin Politik İstikrarsılılı Endeksleri: 1955 - 2009”, Sosyoekonomi, January-June, 2014-1, 9-30.

TOSUN M.U., ULUCAN, A., GÜRAN, M.C. (2008), "The Political Instability, Investment Profile and the Macroeceonomic Performance of Middle East and North African (MENA) Region", Problems and Perspectives in Management, $6(2), 22-40$.

YAYLA, A. (2004), İstikrarsızlı̆ga İhtiyacımız Var, (www.liberaldt.org.tr/yayla/ay-istikrarsõzlõk.htm) Aktaran, Hüseyin Öztürk (2004), Siyasi İstikrarsızlı ve Ekonomi Üzerindeki Etkileri: Türkiye Uygulaması (19502003), Yayınlanmamış Yüksek Lisans Tezi, Süleyman Demirel Üniversitesi, Isparta

YALÇINKAYA, A. E., ŞANLISOY, S., AYDIN, Ü. (2016), "Türk Bankacılık Endüstrisinde Performansın Belirleyenleri ve Politik İstikrarsızlık İlişkisi”, Sosyoekonomi, 24 (27), 161-182. 
Dokuz Eylül Üniversitesi İktisadi ve İdari Bilimler Fakültesi Dergisi Cilt:32, Sayl:2, Yll:2017, ss. 207-237

YÜKSEL, İ., DAĞDEVIREN, M. (2007), "Using the Analytic Network Process (ANP) in a Swot Analysis - A Case Study for a Textile Firm", Information Sciences, 177(16), 3364-3382.

ZABLOTSKY, E. (1996), Political Stability and Economic Growth. A Two Way Relation,

http://www.ucema.edu.ar/publicaciones/download/documentos/109.pdf (12.05.2015)

ZiVOT, E., ANDREWS, D. W. K. (1992), "Further Evidence on the Great Crash, the Oil Price Shock and the Unit-Root Hypothesis", Journal of Business \& Economic Statistics, 10(3), 251-270. 